\title{
Pedro Lemebel's Mi Amiga Gladys: The Role of Emotions in the Reconstruction of Fragmented Memories
}

\author{
JULIO URIBE UGALDE
}

\begin{abstract}
The last book by the Chilean writer Pedro Lemebel (1952-2015) is entitled Mi Amiga Gladys (2016), a production entirely dedicated to his friend Gladys Marín (1938-2005). To date, this work has attracted little attention from academia, perhaps due to its apparently less confrontational discourse, one of the common characteristics of Lemebel's previous works. However, this essay proposes that Lemebel's last book in fact reveals a political statement, yet disguised as an intimate/sensitive declaration. This element would reflect a literary strategy employed by the writer, possibly aiming at eliciting a sympathetic response from the reader, by appealing to his/her emotions. By drawing on Affect theory, this essay argues that Lemebel's personal/emotional stories with Gladys aim at recuperating her legacy, highlighting his friend's social commitment and spirit of resistance. His contribution is indeed relevant to Chilean culture, as Lemebel views Chile's recent past, so arguably conflicted and fragmented in its post-dictatorship period (from 1990 onwards). This study aims at being an innovative contribution to Lemebel's studies, as it approaches his political discourse from an affective perspective, possibly establishing an original model for future analyses of his work.
\end{abstract}

Keywords: Pedro Lemebel; Gladys Marín; Chilean literature; memory; affect

He tenido tanto cariño de los sencillos, modestos, de los que nada tienen y todo les debiera pertenecer, porque ellos hacen el mundo todos los días, los trabajadores.

(Gladys Marín, Estocolmo 2003)

\section{Introduction}

In the preface of the Chilean writer Pedro Lemebel's first work (La esquina es mi corazón) Carlos Monsiváis proposes that this text inaugurates a new perspective of writing literature in Chile, as Lemebel becomes a voice that represented the voiceless: "la inmersión del ghetto en la ciudad" (in Lemebel 
1995: 12). Monsiváis certainly anticipates the essence of Lemebel's future texts, which kept marginality at the centre of his narrative, demonstrating his concerns with recuperating memory in Chile's "amnesic" society. In this regard, several academic studies in fact argue that memory in Chile's post-dictatorship society (from 1990 onwards) reflects fragmented views of the country's recent historical past (Wilde 1999, Richard 2002, Piper 2010, Lira 2011).

However, memory is not only related to politics in Lemebel's literature, as in relation to the disappearance of Chilean citizens during Pinochet's regime. There is also a personal memory imprinted in his work, which he particularly explores in his posthumous work Mi Amiga Gladys (2016). ${ }^{1}$ This text comprises a brief compilation of 10 crónicas and one interview, where the writer shares his personal experiences with the political activist Gladys Marín (1938-2005), revealing emotions that not only traverse from bliss to sorrow, but which also depict a more intimate and reflective side of the author, unseen in his previous publications. This aspect makes this production unique, while it also signals a departure from the writer's most canonical/rebellious works. Probably, this is the reason why the academia has not found this text as revolutionary as his earliest works. Proof of this is that to date, Mi Amiga Gladys has attracted little scholarly attention.

Lemebel's posthumous book can be considered a showcase of his friendship with Marín and an open door to a relationship based on admiration, ideology and affection. However, most importantly, this production unveils the writer's attempt to recuperate Marín's social commitment during Chile's democratic reconstruction process. This essay argues that Lemebel's text functions as an instrument that struggles to keep Marín's memory alive by showing aspects of her personality that were unknown before its publication. This study pays special attention to the literary articulation of emotions as present in this book. It supports this idea by drawing on the Affect Theory (Massumi 1995, Clough 2007, Hogan 2011, Armstrong 2014, Atkinson \& Duffy 2015, Hogan 2016, Bailey \& DiGangi 2017), arguing that emotions are construed in the text seeking an empathic response from the reader. This strategy would elicit the recuperation of fragmented views of the past, allowing their reinterpretation, and guided by Lemebel's depiction of his friend Gladys as an example of perseverance, resistance and spirit of justice.

\footnotetext{
Although Lemebel was unable to see this work come to fruition, the book editor states in the preface that since 2012 the writer worked closely on this project, selecting the texts and images that he wanted to publish, therefore the result actually echoes his original idea (in Lemebel 2016: 9).
} 


\section{Remembering Gladys Marín's Legacy}

Gladys Marín was a Chilean Communist Party member, elected as Congress deputy in 1965. In 1974, she was forced to flee into exile in the Soviet Union, shortly after Augusto Pinochet (1915-2006) overthrew Salvador Allende (1908-1973) in the 1973 coup. Her husband, Jorge Muñoz (1933-?), was kidnapped, tortured and disappeared in 1976. The couple had two sons, with whom Marín was only able to stay in touch through letters during ten years of exile and living underground. After almost five years in Moscow, Marín returned to Chile illegally in 1978 and lived under various aliases to escape detection and repression by the dictatorship's intelligence forces until 1990 when democracy returned to Chile and Marín resumed her public life. In 1994 she became the Secretary-General of the Chilean Communist Party. In 1998, Marín filed the first lawsuit against Pinochet for human rights violations, and in 1999 she ran for president, although she was not elected (Estrada 2005: para. 10).

The documentary "Gladys" (2008) directed by Rodrigo Araya reviews some of the afore-mentioned biographic episodes in Marín's life, demonstrating a history of tenacity and political conviction. Besides that, Araya's work is particularly relevant in that it collects unreleased footage of Marín's public interventions, highlighting her unique and defiant voice during the first years of Chile's return to democracy. It is relevant to recall that after Pinochet, Chile began a democratic process led by a centre-left coalition named $L a$ Concertación. Although the first governments of this alliance were expected to reconstruct a renewed Chile free of Pinochetismo, they were unable to leave his influence behind, mainly because the former members of the military government were still part of the oppositional political side. Nelly Richard asserts that this process indeed unveils a "pact" between La Concertación, Pinochet and the Chilean right wing (2002: 189).

Araya's documentary shows that in those times, Marín was aware of this "pact", as in one of her speeches she boldly critiqued La Concertación's inability to get rid of Pinochet's authoritarian legacy, stating that:

Aquí hay un gobierno civil, democrático, pero junto a él, entrampándolo, tutelándolo, está el poder paralelo de Pinochet, y la derecha económica y política sostenedora de la dictadura, hoy vuelve en gloria y majestad (Marín in Araya 2008: 54:35-55:00).

Marín's speeches also used to demonstrate her unquestionable commitment to the lowest social classes: the always-neglected groups of Chilean society. Her 
URIBE UGALDE

words addressed the workers, the women, the young people, the artists and the Mapuches, those citizens who would still remain invisible in Chile's democratic period. In such public interventions, it is possible to see Marín's engaging role, as she connected very well with vulnerable people. She used her experience as an example of subaltern resistance, calling upon social groups not to give up their "fights." She argued that the dictatorship had once tried to destroy the Communist Party, yet they were still standing, always ready to fight with and for el pueblo (ibid. 51:47-52:27).

Marín's voice during the first transition years in Chile was certainly relevant, as the political activist dared to denounce the continuation of Pinochet's authority in the country. For instance, she once stated that Pinochet was dueño y señor in Chile, suggesting that his military retirement had been strategically planned by the government (ibid. 59:24-59:36). With this statement, Marín anticipated the dictator's future, given that Pinochet in fact retired as Commander-in-Chief of the Chilean Army in 1998 in order to become Senator for life. This agreement had been established in the Chilean constitution of 1980 signed under his rule, benefiting all former Chilean presidents.

Pinochet's influence in democratic Chile was also evident in the governments' failure to offer justice to the families of the detainees-disappeared. Alexander Wilde asserts that the first Concertación governments "suffered frustrating public defeats in attempting [to] resolve pending prosecutions of human rights violations, in spite of having given the highest priority to their policies" (1999: 480). Although the former President Patricio Aylwin (1918-2016) made some gestures, like the establishment of a Commission for Truth and Reconciliation (the Rettig Commission), or his symbolic plea for the families' forgiveness, the governments were unable to offer justice by condemning Pinochet as the head of Chile's genocide. In this scenario, Marín's collaboration in presenting a criminal lawsuit against Pinochet in 1998 was certainly historical. Eduardo Contreras, the lawyer in charge, recalls that this episode changed Chilean history, as this event became known not only in Chile but also worldwide (in Araya 2008: 1:06:00-1:08:00). Contreras argues that this moment possibly influenced Pinochet's arrest in London that same year, when he was charged with human rights violations. After this episode, Pinochet was finally extradited to Chile, where a trial was expected. However, in 2000 all charges against him were dismissed for medical reasons and he died in 2006, without effective imprisonment.

After Pinochet's judicial exoneration, Marín continued her leadership of the Communist Party until 2003 when she was diagnosed with brain cancer. 
That same year she travelled to Sweden and Cuba, following medical treatment. In 2004, she returned to Chile, notably affected by chemotherapy. Despite this, she demonstrated her conviction that she would recover and would soon take over her political duties. However, in a short time her health deteriorated again and she died in March 2005.

Ever since, Chilean media remembers Marín on every anniversary of her death, usually highlighting the transitory aspects of both her personality and political role, yet very seldom recalling her actual legacy. An example of this can be seen in the article published by BioBio in 2019 on the anniversary of Marín's death where her memory seems to act as a "hook", helping to contextualise current political issues. ${ }^{2}$ The text concentrates on Chile's evolving feminist demands, using Marín's image as a feminist icon, yet not providing further information about her actual political value as a woman. On the contrary, the text indeed focuses on the current Secretary-General of the Chilean Communist Party Guillermo Teillier's opinions about current unrelated political topics, emphasising his dissatisfaction with the government's agenda and biased position regarding Venezuela's critical situation.

Another emblematic episode is the failed "kiss" between the right-wing politician Joaquín Lavín and Marín for a Teletón event. Teletón is a Chilean charity campaign usually held annually, which seeks to raise funds for children with disabilities. In its 2000-year version, Lavín proposed to donate \$ 57,000 if Marín gave him a little kiss (piquito) in public. The kiss was expected to be historical, symbolising political unity and reconciliation between both political wings. However, Marín rejected Lavín's proposal, stating that truly generous people would donate money anonymously and without making of Teletón a political business. The press briefly covered Marín's response, emphasising her refusal, thus contributing to the "spectacle" prepared by the right-wing politician. Years later, a complete video of her declaration was published on the Internet, showing that her entire statement had been censored. In the video, Marín appears criticising not only politicians like Lavín but also the powerful economic groups that "clean up" their image by publicly supporting Teletón every year:

Hay gente en este país, y hay grupos en este país que pueden aportar en este segundo más de 40 millones de pesos. Si los grandes grupos económicos de este país, me estoy refiriendo al señor Angelini, al señor Said, a los Matte, a

2 Viewed 13 August 2019 <https://www.biobiochile.cl/noticias/nacional/chile/2019/ 03/09/pc-conmemora-aniversario-de-muerte-de-gladys-marin-y-pide-al-gobiernoatender-demandas-del-feminismo.shtml> 
Luksic, a las transnacionales, la CTC, la Endesa España. Si ellos aportan el 1\% de sus utilidades se completa la Teletón en forma permanente y además se soluciona el problema de la salud en este país [...] Las diferencias no se solucionan en la subasta, ni en un espectáculo, ni en el mercado, yo para eso no, y lo digo en beneficio de la nobleza y del contenido más profundo que tiene la Teletón. Los que tienen plata, sin necesidad de estar haciendo propaganda, que entreguen la platita ahora $[. .$.$] sin condicionamiento y sin hacer de esto un espectáculo.$ (Teletón. Gladys Marín Palabras Censuradas 2011: 01:13-03:00)

The manipulation of information by the Chilean media has been present since the dictatorship years. Then the government blocked all types of political press, clearing space for the two press holdings that represented the military government's ideology: El Mercurio and Copesa (Poblete 2007: 247). To date this oligopoly still keeps its hold on Chilean society, representing $95 \%$ of the national press coverage, as reported by a FUCATEL (Observatorio de medios de comunicación) study in 2015. The owners of these groups represent the most powerful families in the country, with a strong position in various commercial/ industrial areas (press, telecommunications, forestry, fisheries, retail, etc.). Some of these families are the same that Marín had denounced in the aforementioned statement, and probably the reason why she was then censored. This is a simple demonstration of the influence of economic power in Chile, which Tomás Moulian states is conjoined with military and political control (2002: 27), and united in order to maintain the mutually beneficial status quo that has helped to keep their hegemonic position in democratic Chile.

Perhaps, that is why Marín's image has been depicted in the national media as a symbol of "innocuous" political subversion, becoming a "romantic" memory of Chile's recent past. Maybe she has been regarded as an "inconvenient" role model for today's docile Chilean society, given her well-known spirit of insubordination and popular support. Following Alexander Wilde, we could state that Marín has become part of an "irruption of memory", which he describes as "public events that break in upon Chile's national consciousness, unbidden and often suddenly, to evoke associations with symbols, figures, causes, ways of life which to an unusual degree are associated with a political past that is still present in the lived experience of a major part of the population" (Wilde 1999: 475). It is argued that in Chile, the practice of memorising fragmented versions of history, has indeed contributed to creating a blurry and imprecise perception of the country's recent past. While this phenomenon has mainly affected the younger generations, it has also contributed to maintaining the country's passiveness, ensuring the stability of political alliances. 
In this scenario, Isabel Piper argues that Chile is in the process of an inconclusive battle of remembrance, mainly because memory has been formed by incomplete versions of history. Current artefacts of memory are exposed as authoritative voices of the past. They recreate subjective, fragmented images that influence younger generations, thus interfering with their own views of history (Piper 2010: 186). Elizabeth Lira complements this assertion by proposing that the memory of the victims of the dictatorship "has prevailed over other memories" in Chile (2011: 125). The problem, she clarifies, is that this type of memory "tends to be relegated to anonymity, the history of life and struggle reduced to the commemoration of tragedy, persecution, and death" (Ibid.). Consequently, memory remains as a peripheral theme that evokes a past unconnected to the present.

Herbert Marcuse states that the people exposed to this impartiality are in fact "indoctrinated by the conditions under which they live and think and which they do not transcend" (1965: 98). In this regard, it is necessary to help these individuals think autonomously, showing them the differences between true and false versions of history, so they can be freed from indoctrination (Ibid). In this scenario, the role of artists and intellectuals is fundamental. For Joan Scott, writing must be put at the service of transparency because writing is knowledge, and "knowledge is gained through vision": "seeing is the origin of knowing. Writing is reproduction, transmission - the communication of knowledge gained through (visual, visceral) experience" (1991: 776). For Nelly Richard, art has the responsibility to ask questions about the problems of the past in order to recuperate memories of truth. It is necessary to debate on what, how and why memory is necessary (2002: 193).

In Mi Amiga Gladys, Lemebel aims at recuperating the political activist's memory by offering narrations that depict intimate histories of friendship. However, where the writer's approach might seem "innocuous", given the emotional burden inspired by Marín, I would argue that Lemebel's book is in fact a political instrument that allows recuperating "true" memories. His crónicas show a different side of his friend Gladys, perhaps more personal, yet connected with the politician's social commitment, highlighting her actual value. As we have seen, this is an aspect that seems blurry in today's Chilean society, and which has in fact been controlled by the national media.

Lemebel's book is a reminder not to forget, a contribution to reconstruct memory. Nevertheless, this work's actual uniqueness is the literary articulation employed by the writer in order to achieve such reconstruction of memory. It is proposed that Lemebel plays with emotions in such a way that they reflect a 
strategy to catch the reader's attention. They make the reader susceptible to a poignant involvement, elicited through an emotional literary experience.

In order to understand the writer's approach, it is necessary to discuss how emotions might potentially engage the reader, following a superior goal. In this case, this goal is to reposition the image of his friend Gladys by exposing his personal memories, the "true" memories of a man who wishes his friend not to be forgotten.

\section{Lemebel's Mi Amiga Gladys, Memories from the Heart}

Lemebel's Mi Amiga Gladys is a text that seemingly follows a strategic literary/ emotional articulation that might pursue the readers' engagement with the writer's own appraisal. This could be explained as Lemebel's attempt to recuperate the image of his deceased friend Gladys ${ }^{3}$ in Chile. As we have previously seen, after the dictatorship, conflicting versions of history have surfaced. In some cases, the national media has had a direct impact on this, helping to create fragmented memories, which have interfered with the country's realistic views of the recent past.

It is argued that in this book, as in his entire work, Lemebel performs an act of subversion that defies the national status quo. Following Frederic Jameson, we could state that the Chilean writer identifies a fracture, as if demonstrating that something was not in place. Jameson proposes that a cultural text is deployed at a level that interferes with another, as a "subversion of one level by another" (1981: 41). In this regard, the "object of study emerges only when the appearance of formal unification is unmasked as a failure" (ibid.). Consequently, it could be stated that Lemebel's last book identifies a fracture of national memory that directly interferes with his friend's public image. His political position is then mixed with emotions, to the point that both collide. That clash might have given birth to this book, a collection of memories... subversion from the heart.

Lemebel's emotions as an element that conforms a literary/subversive strategy can be analysed and understood from the perspective of Affect Theory. In their study on Affect, Paul Atkinson and Michelle Duffy state that this concept in "contemporary theory marks a return to the body as a site for the interplay of thought and feeling" (2015: 94). This means that from this standpoint, the status of the body changes. It is no longer the container of the

3 From this point onwards, I will refer to Gladys Marín by her first name, in order to maintain the intimacy that the writer attempts to create in the book. 
mind, yet the "very condition for the transmission or distribution of affect" (ibid.).

Patricia Clough also refers to the relevance of Affect Theory by drawing on the term "Affective Turn." Clough explains that this concept unveils a critical theory that privileges the individual's affective responses in order to theorise the social, the historical and the political (2007: 3). To come to this conclusion, Clough reflects on Deleuze and Guattari's concept "body without organs", included in their publication Anti-Oedipus. Capitalism \& Schizophrenia (1983). In simple terms, Deleuze and Guattari's concept proposes that people's bodies are employed as an instrument of material production. Clough sustains that this proposition was fundamental in order to reposition the body as a topic of discussion in academia, unveiling connections between the study of emotions and politics.

Amanda Bailey and Mario DiGangi further study the link between politics and emotions in their book Affect Theory and Early Modern Text (2017). They state that,

an affective account of politics will tend to emphasize not the grand narrative but the everyday feeling; not the unidirectional operation of disciplinary authority but the mutually impactful bodily encounter; not the singular agency of an individual but the distributed agencies of a collective; not the conscious articulation of political policies, doctrines, or schemes, but the inarticulate stirrings of feeling or "affective cognition" that might move a subject toward unforeseen affiliations, alliances, and actions (2017: 7).

These theoretical notions support the idea that Lemebel's emotions are mixed with his own political convictions, certainly shared with his friend Gladys. In terms of the literary construction of this posthumous piece, we could first affirm that Lemebel employs the articulation of a poetic language that indeed reflects an emotional engagement. Leonidas Morales refers to Lemebel's avantgarde writing technique as estética barroca: a mixture of a metaphorical, yet colloquial language (2009: 230). In the book, such style is demonstrated in the way Lemebel speaks about his friend, for example when he describes her as a "pájaro rojo que entra sin permiso por la ventana del corazón" (2016:36) or as a "ventolera enamorada de la justicia" (ibid. 42). In the first example, Lemebel uses the metaphor "pájaro rojo" to highlight Gladys's inspiring role in the Chilean Communist Party, whereas he coins the term "ventana del corazón” to express her defiance as she came into his life to remain forever in his heart. In the second example, Gladys is compared to a "ventolera", a gust of wind, 
to emphasise her freedom of speech and vigour in her well-known pursuit of justice in defence of the victims of Pinochet's dictatorship.

All crónicas in Lemebel's posthumous book keep Gladys as a protagonist. As his close friend, Gladys inhabits Lemebel's narrations in what could be described from a literary perspective as an "immigrant" participation. Terence Parsons uses both terms "native" and "immigrant" to classify the role of characters in a literary piece. He states that characters are "native" to a story if they are born in the text, while they are "immigrant" to a story if they come to the text from an outer realm, such as the real world (Parsons 2011: 30-31). As such, Gladys is portrayed in the text as a character that the writer knew well. Consequently, he is capable of showing aspects of her personality that were actually unknown before this publication. In particular, the author mainly focuses on her virtues, depicting her as a caring person, concerned about everyone but herself, despite all the suffering endured in the past. Nancy Armstrong suggests that in literature, damaged characters allow a "sympathetic identification" with the reader (2014: 442). This implies that showing the characters' emotional side allows connecting the story with its audience. This assertion would demonstrate that the creation/depiction of such a character, his/her physical and psychological features, as well as the emotions that he/she manifests, are indeed created by anticipating the reader's response.

As stated above, Lemebel portrays several features of Gladys's personality in this book, mainly emphasising her qualities. This might be interpreted as the author's attempt to exalt the image of the political activist, not only as a way to honour both her social commitment and her loyal friendship, but also in order to elicit a sympathetic response from the reader. For example, in "Donde estés y siempre (o tren de la victoria)”, Lemebel highlights Gladys's humility and respect for a group of craftsmen whom both the writer and the political activist come across as they walk in the street. These craftsmen give Gladys costume jewellery which she receives and wears with pride:

Ella los lucía con tanto orgullo como si cargaran miles de manos alambreras. [...] Es el cariño de los cabros, Pedro, son mil alhajas pobres. Yo no nací para diamantes y centollas. (Lemebel 2016: 37)

Likewise, in "Navidad en Andacollo", the author reflects upon Gladys's attitude towards the religious festivity of Andacollo, ${ }^{4}$ which she attended every year.

4 Andacollo is a city located in the region of Coquimbo, Chile. Every year, people gather around the city's basilica to honour the Virgin: Nuestra Señora de Andacollo. This festivity is the most important in Chile's Norte Chico. 
The writer struggles in order to understand her admiration and respect for this popular tradition, suggesting that such belief is not in accord with her communist ideology:

¿Y por qué te gusta tanto ir a esa fiesta religiosa a ti que eres comunista?, la encaré una tarde a Gladys, y ella [...] me contestó: en el asunto de la fe popular hay tanto que aprender, Pedro. No podría pensar que yo tengo la verdad en esos asuntos. (Ibid. 57)

On the other hand, it is possible to glimpse Gladys's social commitment in the crónica "Con Gladys en la Ópera." The writer narrates an episode in which she was invited by the Teatro Municipal de Santiago workers to see La Traviata. Neither of them liked opera, however Gladys persuades Lemebel to accompany her as a way to support the workers' labour demands:

Sabes que los trabajadores del Teatro Municipal nos invitaron a ver La traviata y si quieres podemos ir juntos, me sugirió ella con su ternura habitual. Son los compañeros del teatro, gente super buena onda, además es una manera de apoyarlos en sus demandas laborales, Pedrín, anda di que bueno. (Ibid.61)

In these excerpts it is possible to glimpse the writer's personal point of view regarding his introduction of Gladys as a character, aiming to engage the reader in the same appraisal. He shows a humble, respectful, empathetic and supportive Gladys in order to elicit sympathy and identification in the reader. In this regard, Patrick Hogan's differentiation between empathy and emotional contagion is indeed accurate. Hogan argues that an empathic response "is the feeling state of some other person", whereas emotional contagion is "whatever we take to have caused that feeling state in the other person" (2011: 22). Using this idea, we could infer the latter is the actual strategy employed by the writer, as Lemebel's emotion seems to be transferred to his audience. Here, we could imply that the writer actually anticipates the reader's response, by addressing an "implied reader." Hogan, possibly drawing on Iser (1974), defines "implied readers" as "textually guided simulations that provide norms for response to a literary work" (2016: 17). Although some critics might object to this concept, Hogan argues that keeping an "implied reader" in mind is a literary strategy that helps the author to avoid the reader's misguided emotional response (ib.).

Lemebel's artistic composition could be compared to that of a sculptor, where the clay acts as his memory and the chisel as is his pen. The book becomes an emotional creation that the writer expresses passionately. In this regard, the crónica "Otro Once sin Gladys" is probably the most emotive text in the book, 
where Lemebel reveals his grief for Gladys's death on a new commemoration of September $11 .{ }^{5}$ Every year, Lemebel used to receive a call from Gladys, inviting him to march along the streets of Santiago de Chile; however, September 11 is a black date since she is gone. The following excerpt portrays his agony as he proclaims that,

\begin{abstract}
Este será otro Once sin mi Gladys floreando de claveles rojos la mañana de septiembre. Sin Gladys, por supuesto. Sin su hermosa presencia, dándome la mano cuando llegaban los pacos y quedaba la cagada. [...] y gritaré tu nombre y los nombres de los sin nombre, querida. Gritaré tu nombre demasiado fuerte, para que no se note mi voz trizada llamándote en la ausencia. Gritaré tu nombre Gladita, y tragaré mil lágrimas tratando de acunar la pena en el tibio recodo del corazón. (Lemebel 2016: 67)
\end{abstract}

The writer's grief as imprinted in this fragment might possibly be transferred to his readers if they were capable of simulating his own emotions. Hogan proposes that in literature, "simulation is a key operation of the human mind. It involves the imagination of particulars beyond direct perception and memory. It is the process that we engage in when imagining the way things might play out if we engage in various sorts of activity" (2016: 3). Accordingly, a reader of this crónica could possibly simulate the writer's agony as his own, not necessarily for Gladys's death, but for the pain expressed by the narrator. The reader, if emotionally engaged, could probably contrast the narrator's grief with his own past experiences, asking himself, for example: How would I feel in a similar situation? On which occasions have I felt such a level of agony? Or, who is the person that means as much to me, as Gladys did to Pedro?

The emotional experience of reading Lemebel's last book may be activated by reaching a deep connection with the writer. It is argued that this would only be possible if the reader is capable of simulating the narrator's feelings. On the same line of thought, Brian Massumi introduces the term "Autonomy of Affect" in his 1995 article, where he explains that texts may be emotionally interpreted on two levels: "qualification" and "intensity." Massumi explains that "qualification" refers to deep reactions related to a form/content level, while "intensity" refers to "purely autonomic reactions most directly manifested in the skin at the surface of the body, at its interface with things" (1995: 85). Massumi is particularly engaged with the latter, proposing that physical reactions cannot be semantically or semiotically explained. Therefore, "intensity" is relevant. It

5 On September 11, Chile conmemorates the 1973 armed forces' coup as well as President Salvador Allende's death. 
focuses on that which is indexed as separate and is ignored from a canonical literary perspective. It offers the possibility to analyse a text by paying attention to our emotions. In this regard, a crónica that best explains this proposition is "La ternura insolente de tu mirar." Unlike other texts in the book, this time the writer offers his own reflections rather than remembering previous moments shared with Gladys, as if inviting the reader to join him in his grief. This crónica, written for the first anniversary of Gladys's death, closes the book:

A un año de tu partida, los recuerdos se me cruzan en el aire como pájaros ciegos, como alondras expatriadas; las imágenes no pueden recuperar el color lejano de tu abandono. No sé que decir, pero lo que sí sé es que tú me entiendes, porque aún no despierto, aún no resucito desde aquella noche cruel en que te fuiste, niña mía. Desde entonces no tiene mucho que decir este corazón atolondrado que no se convence cuando le digo que nunca más reiremos juntas, nunca más lloraremos juntas, nunca más marcharemos juntas, nunca más pelearemos juntas por los avatares justicieros de esta patria. Lo cierto es que estas palabras no tienen eco en el abismo sordo de tu ausencia, querida. Lo cierto es que no estás, y eso es todo... (Lemebel 2016: 95) ${ }^{6}$

In sum, Gladys is the inspiration of the writer's work and the representation of different emotions and concepts in each of the crónicas presented; for instance, she is "the past" in "Mi amiga Gladys 'El amor a la libertad es imparable"; " fidelity" in "Mi corazón es un libro abierto"; "supportiveness" in "Inolvidable rareza (o la invitación a "De Pe a Pa")"; "humbleness" in "Donde estés y siempre (o el tren de la victoria)"; "freedom" in "Donde estés y siempre (o "pie de limón en Lumaco")"; "respect" in "Navidad en Andacollo" and "hope" in "La ramada de Gladys." Nevertheless, she also embodies her own absence in the writer's life, as expressed in "Otro Once sin Gladys" and "La ternura insolente de tu mirar", where she is portrayed as the reason of the author's sorrow. Yet, most importantly, Gladys's depiction in this book represents the writer's aim to recuperate her indisputable socio-political contribution. Gladys's contemporaries are aware of her firm convictions and commitment to neglected groups of society; however, as we have seen, younger generations have lately been exposed to fragmented views of history. These "irruptions of memory" are somehow responsible for the gradual fading of Gladys's legacy, although her image reappears in every anniversary of her death, yet as a hackneyed

6 The writer's experience can be simulated at a different level if listening to the recording of this crónica in Lemebel's own voice. This sample is available on https://www. youtube.com/watch?v=8B-Vo4lIPU8 (viewed 12 June 2019). 
URIBE UGALDE

representation of political resistance. Lemebel's Mi Amiga Gladys is a unique work in the writer's oeuvre in that it shows his most intimate emotional side, one that seems to struggle in order to fit within his canonical political work. Lemebel's book defies Chile's conflict with memory loss by bringing back one of the key participants in the country's democratic reconstruction, defying the status quo, and offering a subversive discourse disguised as an emotional recount.

\title{
Conclusions
}

The Chilean Communist Gladys Marín was a canonical figure of political resistance during and after the dictatorship. Particularly in democracy, Marín had a relevant role as an opponent of the tepid first governments, unable to manage Pinochet's authoritarian influence. Marín's bravery in denouncing a political negotiation between left and right was certainly admirable, although her most notable contribution was the criminal lawsuit presented against Pinochet in 1998. Despite her undisputable socio-political role, Marín is today remembered as a "romantic" figure, as a representation of "harmless" defiance. It is argued that the reason for this manipulated image is the consequence of Chile's "amnesic" condition where history has been narrated in fragments, so younger generations have only had access to partial accounts of reality. In this scenario, Pedro Lemebel's posthumous book Mi Amiga Gladys (2016) irrupts as a text that seeks to reposition Marín's role in current Chilean society. The writer employs emotional/literary strategies in order to catch the reader's attention, making him/her a participant of his own emotional memories. His work defies the national status quo by offering a subversive text, seemingly disguised as an "innocuous" emotional recount.

\author{
Julio Uribe Ugalde \\ juliouribeugalde@gmail.com \\ School of Languages and Linguistics \\ Faculty of Arts, The University of Melbourne \\ 139 Babel, Parkville \\ Melbourne \\ AUSTRALIA
}


Pedro Lemebel's Mi Amiga Gladys

\section{Bibliography}

Araya, R. 2008. Gladys. Documentary. Escuela Cine Universidad Arcis. - YouTube, https://www.youtube.com/watch?v=Mqr6ZOiy7FM\&t=859s (19.10.2019).

Armstrong, N. 2014. The Affective Turn in Contemporary Fiction. - Contemporary Literature, 55 (3): 441-465. https://doi.org/10.1353/cli.2014.0023

Atkinson, P.; Duffy, M. 2015. The Amplification of Affect: Tension, Intensity and Form in Modern Dance. - Modernism and Affect. Edinburgh: Edinburgh University Press, 94-110.

Bailey, A.; DiGangi M. 2017. Introduction. - Affect Theory and Early Modern Text. London: Palgrave Macmillan, 1-24.

Clough, P. T. 2007. An Introduction. - The Affective Turn: Theorizing the Social, Patricia Ticineto Clough, Jean Halley. Durham: Duke University Press, 1-33. https://doi.org/10.1215/9780822389606-001

Estrada, D. 2005. Chile: Nationwide Mourning for Communist Leader Gladys Marin. - Inter Press Service, News Agency, http://www.ipsnews.net/2005/03/chilenationwide-mourning-for-communist-leader-gladys-marin/ (19.10.2019).

Hogan, P. 2016. Affect Studies and Literary Criticism. - Oxford Research Encyclopedias, https://doi.org/10.1093/acrefore/9780190201098.013.105 (19.10.2019).

Hogan, P. 2011. What Literature Teaches Us about Emotion. Cambridge: Cambridge University Press.

Jameson, F. 1981. On Interpretation, Literature as a Socially Symbolic Act. - The Political Unconscious. Ithaca: Cornell University Press, 1-88.

Lemebel, P. 1995. La Esquina Es Mi Corazón. Santiago de Chile: Cuarto Propio.

Lemebel, P. 2016. Mi Amiga Gladys. Barcelona: Seix Barral Biblioteca Breve.

Lira, E. 2011. Chile: Dilemmas of Memory. - The Memory of State Terrorism in the Southern Cone, Argentina, Chile, and Uruguay. London: Palgrave Macmillan, 107132. https://doi.org/10.1057/9780230118621_6

Marcusse, H. 1965. Repressive Tolerance. - A Critique of Pure Tolerance. Boston: Beacon Press, 81-123.

Massumi, B. 1995. The Autonomy of Affect. - Cultural Critique, The Politics of Systems and Environments, Part II (31), 83-109. https://doi.org/10.2307/1354446

Morales, L. 2009. Pedro Lemebel: Género y Sociedad. - Aisthesis, 46, 222-35. https:// doi.org/10.4067/S0718-71812009000200012

Moulian, T. 2002. Chile Actual Anatomía de Un Mito. Santiago de Chile: Lom Editores.

Parsons, T. 2011. Fictional Characters and Indeterminate Identity. - Truth in Fiction. Berlin: Ontos Verlag, 27-42.

Piper, I. 2010. Memorias de la Violencia Política en Chile: 1970-2014. - Anos 90, 22 (40), 179-191.

Poblete, J. 2007. Cultura, Neoliberalismo y Comunicación Ciudadana: El Caso de Radio Tierra En Chile. - Cultura y Neoliberalismo, 241-63.

Richard, N. 2002. La Crítica de La Memoria. - Cuadernos de Literatura, Bogotá, 8.

Scott, J. W. 1991. The Evidence of Experience. - Critical Inquiry, 17 (4), 773-797. https://doi.org/10.1086/448612 
URIBE UGALDE

Teletón. Gladys Marín Palabras Censuradas. 2011. - YouTube, https://www.youtube. com/watch?v=XxktTLr6WIE (19.10.2019).

Wilde, A. 1999. Irruptions of Memory: Expressive Politics in Chile's Transition to Democracy. - Journal of Latin American Studies, 31 (2), 473-500. https://doi. org/10.1017/S0022216X99005349 